\title{
Volcanic Characteristics of Kueishantao in Northeast Taiwan and Their Implications
}

\author{
Ching-Lung Chiu ${ }^{1}$, Sheng-Rong Song ${ }^{1, *}$, Yu-Chung Hsieh ${ }^{2}$, and Chi-Xuan Chen ${ }^{2}$ \\ ${ }^{1}$ Institute of Geosciences, National Taiwan University, Taipei, Taiwan, ROC \\ ${ }^{2}$ Central Geological Survey, Ministry of Economic Affairs, Taipei, Taiwan, ROC
}

Received 23 March 2008, accepted 22 February 2010

\begin{abstract}
Kueishantao (KST) is a small offshore volcanic island located at the southernmost part of the Okinawa Trough. In this study, we conducted a detailed mapping incorporating the new high resolution LiDAR DTM laser scanning device to accurately construct a volcanic sequence. A new 1/5000 geological map was established. One primary volcanic cone, composed of layers of both lava flows and pyroclastic rocks constituted the major edifice of KST. The other minor volcanic cone, which consists of volcanic lapillis and blocks, is seated to the east of the main cone. The escarped and nearly straight coast in the southern part of the KST indicates that the volcano suffered a large post-volcanic edifice collapse erasing nearly one half of the volume of both volcanic cones. The increase in the abundance of the xenoliths of sedimentary rocks from the lower to the upper part of the volcanic sequence indicates that the formation of volcanic rocks of the KST involved an intensification of crustal contamination. The possibility of volcanic eruption can not be excluded in the future based on the present thermoluminescene age data of $7 \mathrm{ka}$. The associated eruptive ash fall and tsunami induced by the further collapse of the KST volcanic edifice might have great influence to the adjacent inland. Thus, long-term monitoring of volcanic activities around KST should be required for future hazard assessments.
\end{abstract}

Key words: Kueishantao, Okinawa Trough, Ryukyu arc, Lava flows, Stratovolcano

Citation: Chiu, C. L., S. R. Song, Y. C. Hsieh, and C. X. Chen, 2010: Volcanic characteristics of Kueishantao in northeast Taiwan and their implications. Terr. Atmos. Ocean. Sci., 21, 575-585, doi: 10.3319/TAO.2010.02.22.02(TH)

\section{INTRODUCTION}

KST is a young volcanic island located at the tectonic conjunction of the Ryukyu arc and the southernmost part of the Okinawa Trough (SPOT)(Fig. 1). The Okinawa Trough, extending from SW Kyushu to NE Taiwan, is generally considered to be intracontinental backarc basin behind the Ryukyu arc-trench system due to subduction of the Philippine Sea plate beneath the Eurasian plate (Lee et al. 1980; Letouzey and Kimura 1986; Sibuet et al. 1998). Chung et al. (2000) suggested that the SPOT, however, is not a simple backarc basin but instead an embryonic rift zone in which early arc volcanism occurs as a result of the Ryukyu subduction. All the SPOT lavas (including KST) show calcalkaline affinities and may be explained as products of early arc volcanism caused by the southwestward propagation

\footnotetext{
* Corresponding author

E-mail: srsong@ntu.edu.tw
}

of the Ryukyu subduction zone. Sibuet et al. (1998) suggested the opening history of the SPOT can be divided into two phases: $\sim 2$ - $0.1 \mathrm{Ma}$ and $\sim 0.1$ - present day. Liu (1995) reported that the rifting of the Okinawa Trough has been extending through KST into the I-lan Plain.

Chen et al. (2001) reported a thermoluminescene (TL) age of $7 \mathrm{ka}$ for the lower part of the volcanic sequence, indicating that the last volcanic eruption occurred sometime after $7 \mathrm{ka}$. Further, Yang et al. (2005) reported that bubble gas samples collected from the sea surface and submarine around KST exhibit a significant high ${ }^{3} \mathrm{He} /{ }^{4} \mathrm{He}$ ratios (7.35 - $8.39 \mathrm{R}_{\mathrm{A}}$ ), indicating that the mantle component plays an important role for their gas sources which implies that the magmatic activity beneath KST area must be considerably active. In short, based on the above-mentioned reports, the KST volcano can be identified as an active volcano according to the definitions by the International Association of Volcanology and Chemistry of the Earth's Interior 


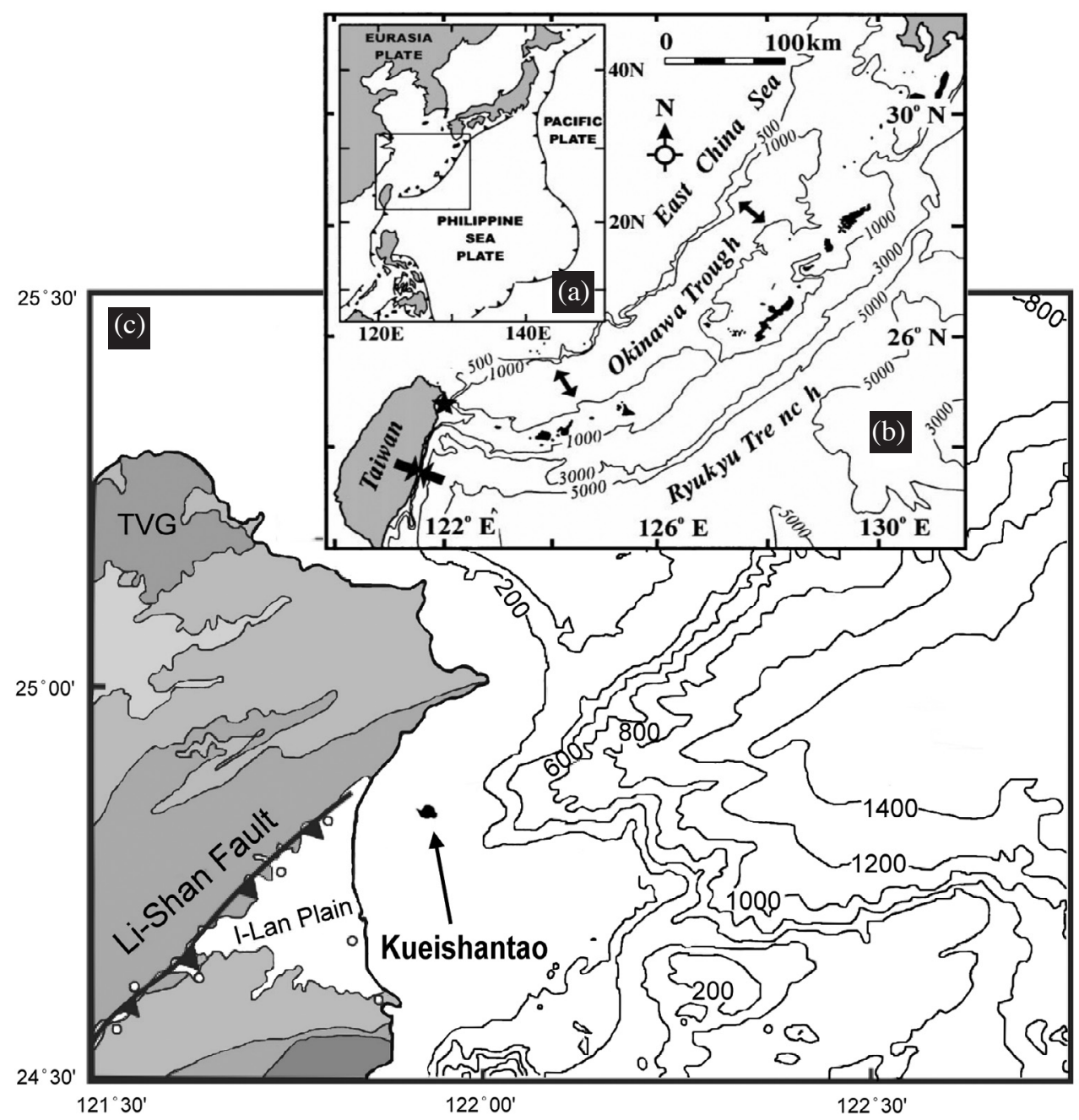

Fig. 1. Location of the study area. (a) The tectonic frameworks around the west Pacific. (b) Map showing the geography surrounding the Okinawa Trough which extends from SW Kyushu, Japan to NE Taiwan. (c) The Kueishantao volcano is located at the southwestern part of the Okinawa Trough. TVG: the Tatun Volcano Group. Map modified from Yang et al. (2005) and Chen et al. (2001).

(IAVCEI)(Szakacs 1994). Thus, the potential for eruption of the KST volcano can not be ignored and a long-term monitoring program for volcanic activities around KST is definitely necessary. The purpose of this paper is to study the characteristics of the KST Volcano and its potential volcanic hazard.

\section{THE GEOMORPHOLOGY OF KST}

In this study, we utilized the new high-resolution LiDAR DTM to examine the volcanic features to accurately distinguish the boundaries of different volcanic units. Previously, the DTM used in Taiwan had resolutions of $40 \mathrm{~m}$ $\times 40 \mathrm{~m}$ and $10 \mathrm{~m} \times 10 \mathrm{~m}$ and was not sufficient to map detailed volcanic structures and sequences. Recently, LiDAR images of KST have been published by the Central Geological Survey (CGS), Ministry of Economic Affairs (MOEA) providing a high resolution DTM of $2 \mathrm{~m} \times 2 \mathrm{~m}$ for this study.

Because its appearance is similar to a sea turtle, the KST is generally divided into three topographic parts, which were named Kueitou (turtle-head), Kueichia (turtle-shell), and Kueiwei (turtle-tail), from the east to the west (Fig. 2).

\subsection{Kueitou}

Based on the topographic analyses and filed surveys, the Kueitou has the shape of a half cone which is mainly composed of pyroclastic flow deposits. As a result of a poor cementation of these deposits caused by strong hydrothermal alteration, the eastern part of Kueitou has collapsed and formed a cliff. Topographically, Kueitou is low in the west and high in the east with over 200 meters in elevation. The stratum of ash fall deposit covered at the surface of Kueitou unconformably lies on Kueichia with a dip angle about $30^{\circ}$ to the west (Fig. 3a). 

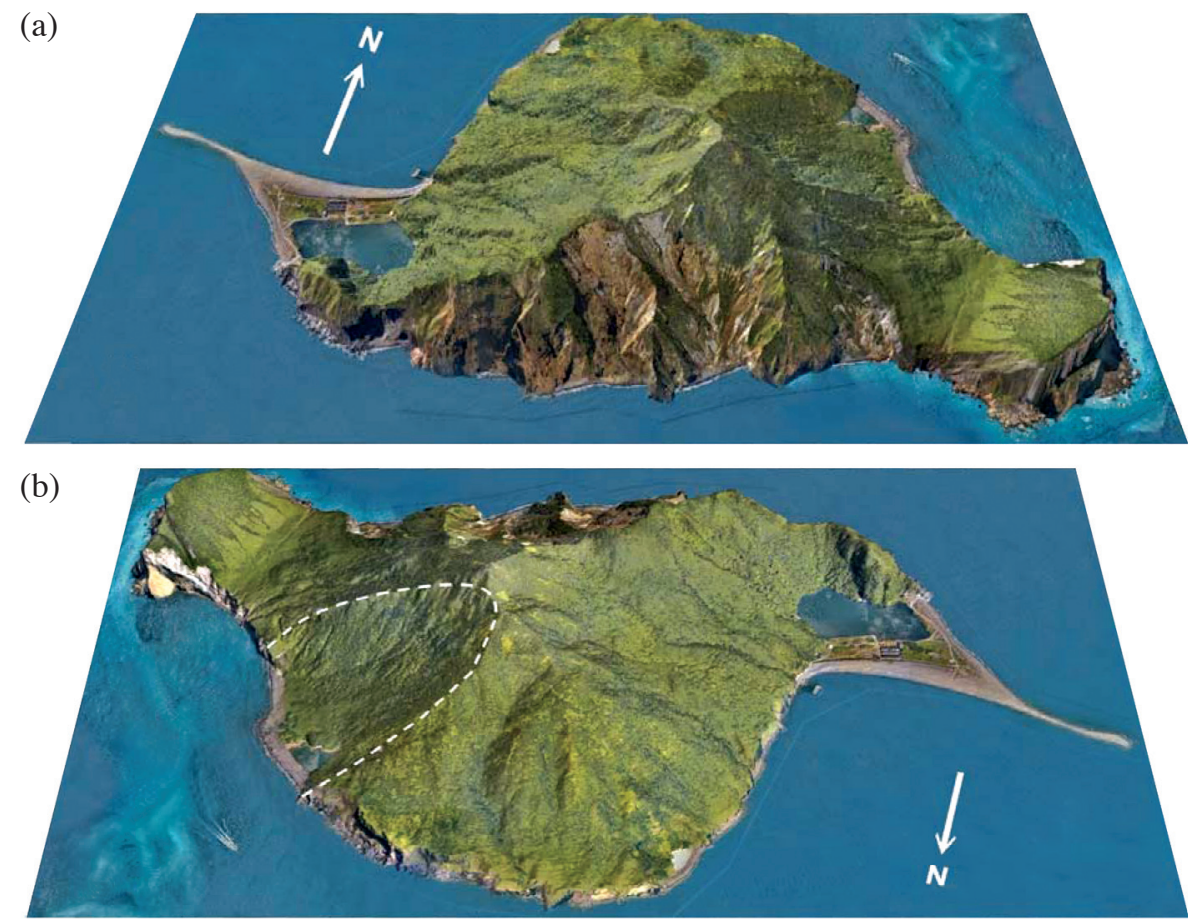

Fig. 2. 3D simulated images produced by aerial ortho-photograph LiDAR DTM processing. (a) KST can be divided into three parts: Kueitou, Kueichai, and Kueiwei, from the east to the west. (b) A concave edifice found at the northeastern flank of Kueichia which was probably induced by a landslide. The white dashed line shows the outline of landslide.
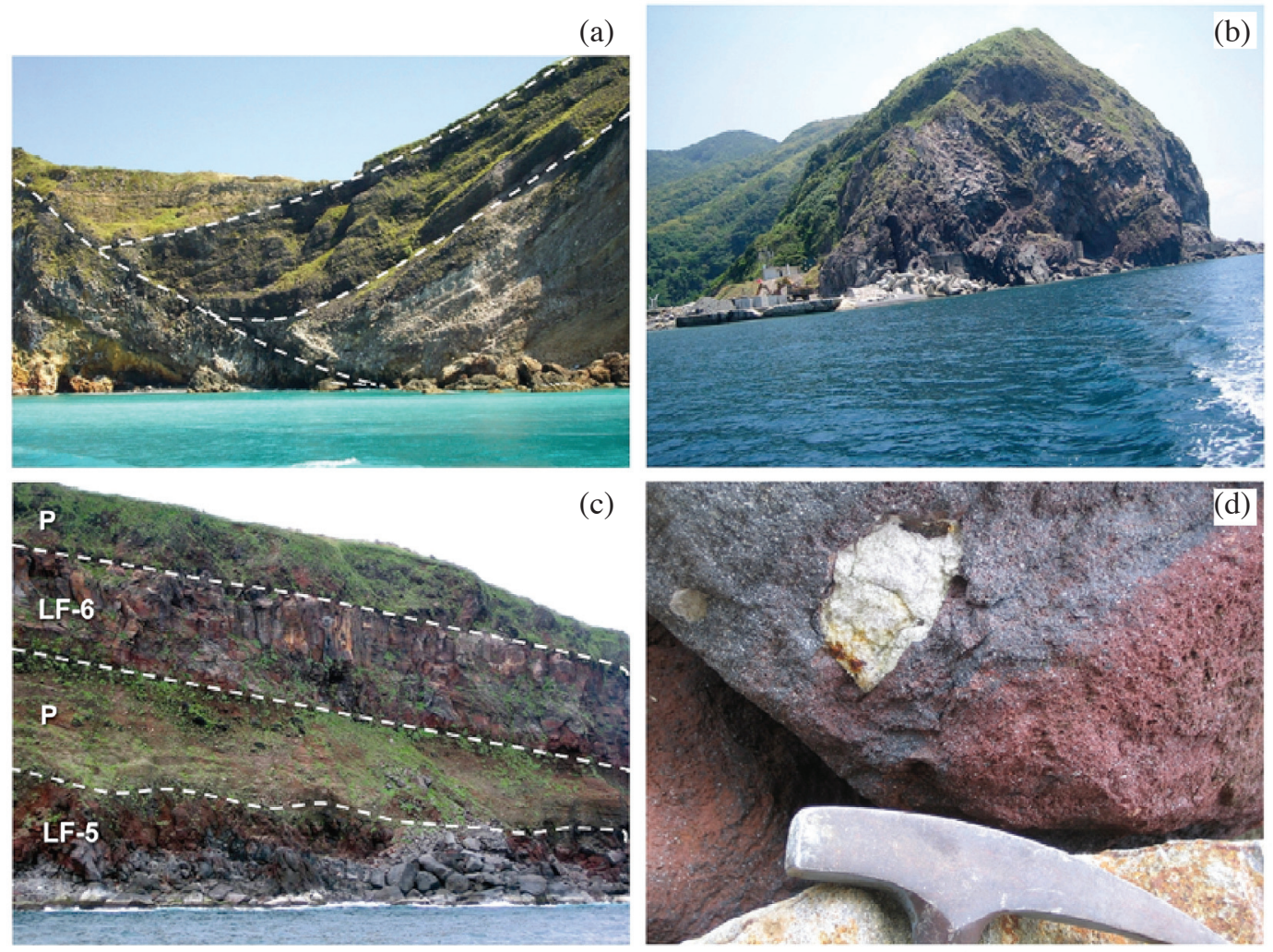

Fig. 3. Field photographs of KST. (a) The stratum of ash fall deposit covered at the surface of Kueitou unconformably lies on Kueichia with a dip angle about $30^{\circ}$ to the west. (b) A hill located at southwestern Kueichia is formed by a lava dome. (c) LF-5 and LF-6 both possess reddish surface exposed at the northern shore. P: pyroclastic flow deposit. (d) A xenolith of quartzite exists in a reddish block. All white dashed-lines show the boundary of strata. 


\subsection{Kueichia}

Kueichia is the main part of KST with a roughly rectangular shape and has a maximum height of 401 meters. It is topographically steep in the southern part, but is mild in the northern part. A lava dome, forming a small hill, is located at the southwestern part of Kueichia (Fig. 3b). On the southern cliff, hydrothermal activity is still active, and thus some rocks have been partly altered. Several lavas flow towards the north and the northwest formed a mild fan-shaped hillside with a gradient of about $30^{\circ}$. In addition, some lava ridges are radially dispersed westward along the whole of Kueichia. It is interesting to note that a concave edifice is found at the northeastern flank, which may be caused by an edifice collapse (Fig. 2).

\subsection{Kueiwei}

Kueiwei is a long piece of land, which consists of gravel mainly eroded from andesites of Kueichia, stretching out towards NWW for about 1 kilometer. It has a maximum altitude of 4 - 5 meters.

\section{DISTRIBUTIONS OF VOLCANIC ROCKS}

The possibility of volcanic eruption can not be excluded in the future. The lava flows and pyroclastic deposits of KST are mainly composed of basaltic andesites. Both Kueitou and Kueichia have only the remains of half of a volcano. It is very likely that the eastern part of Kueitou and the southern part of the Kueichia have already collapsed into the sea (Hsu 1963). The occurrence of xenoliths in the KST volcanic rocks is quite common. The xenoliths should be the basement rocks which were brought up with upwelling magma, mainly including quartzite, schist, sandstone, etc. This rock assemblage is petrographically similar with the strata of NE Taiwan, indicating that the basement rock of KST is under the same framework of NE Taiwan (Hsu 1963; Chen 1990).

According to field investigations, the composition of volcanic rocks at KST include lava flows, ash fall deposits, pyroclastic flow deposits, lahar deposits and hydrothermally altered rocks (Fig. 4). Among them, lava flows and pyroclastic flow deposits are most widely distributed over KST.

The KST is predominantly composed of lava flows with basaltic andesites in composition. Topographically, the lava flow can be distinguished into the lava plateau, ridge and dome. The distributions of the lava flows are mainly found along the northern and northwestern flanks of KST which radiate predominately from the summit and form fan shapes. Thicknesses vary upward to tens of meters. Several lava ridges, radiating from the summit to the coast are also distributed along the northern and northwestern flanks of KST. Strata of Aa lava flow with brown-reddish surface and abundant vesicles are exposed near the sea surface at the west of KST (Fig. 3c) and are characterized by loose, broken, sharp and clinker surfaces covering the massive and dense interiors. Those lines of evidence indicate that they were probably formed by gas-rich magma which erupted in the subaerial and thermal-oxidized with air.

A lava dome, forming a small hill, is located at southwestern KST. It is characteristic of massive and randomdirectional radiated platy joints with vertical columnar underneath it in KST. Its distinctive dome shape probably resulted from the slow extrusion of higher viscous lava from a parasitic cone.

The pyroclastic flow deposits mainly distribute at Kueitou, and the south and southwest of Kueichia. They are predominantly composed of angular to subangular lapilli and blocks with fine crystals, and partly interlayered with the lava flows. The lapilli and blocks are monolithologic andesite rich in dark mafic and white plagioclase phenocrysts with cooling radiated fractures. The characteristics of this occurrence suggest that they are formed by block and ash flows or debris flows which originated by collapse of a dome or volcanic edifice, respectively (Cas and Wright 1987).

The ash fall deposit formed by eruption debris is distributed about at Kueitou and in its western part. The thin and clast-supported characteristic indicates that KST had a tendancy for weak explosions.

As for the lahar deposit, it was formed by volcanic materials mixing with water and occurs sporadically in the northwest and the west of Kueichia. They are usually poorly sorted and matrix-supported with subangular to subrounded blocks. It was formed by loose volcanic products mixed with surface water or groundwater during or after eruptions and accumulated at about the distal apron. The hydrothermally altered rocks are distributed in the northwest, the northeast and the south of Kueichia and characterized by loose white materials rich in silica minerals such as chalcedony or christobalite.

\section{SEQUENCE OF VOLCANIC ROCKS}

Both K-Ar dating (Juang and Chen 1989) and TL dating (Chen et al. 2001) show that the latest eruption stage of KST should be young and partly explains the well preserved volcanic topography of KST. Accordingly, we can determine the sequence of lava flows in terms of the characteristics of topography using the LiDAR DTM with $2 \mathrm{~m} \times 2 \mathrm{~m}$ resolution, cross-cutting relationships and field occurrences of lava flows. Hsu (1963) first reported the geological map of KST wherein all of the sequences or lava flows had the dips to the north. However, some of the geological descriptions have proved to be incorrect. As we described previously, for example, the dips in the volcanic sequence in Kueitou are to the west and some of the lava to the southwest. Therefore, in order to proceed further study, an updated geological map 
(a)

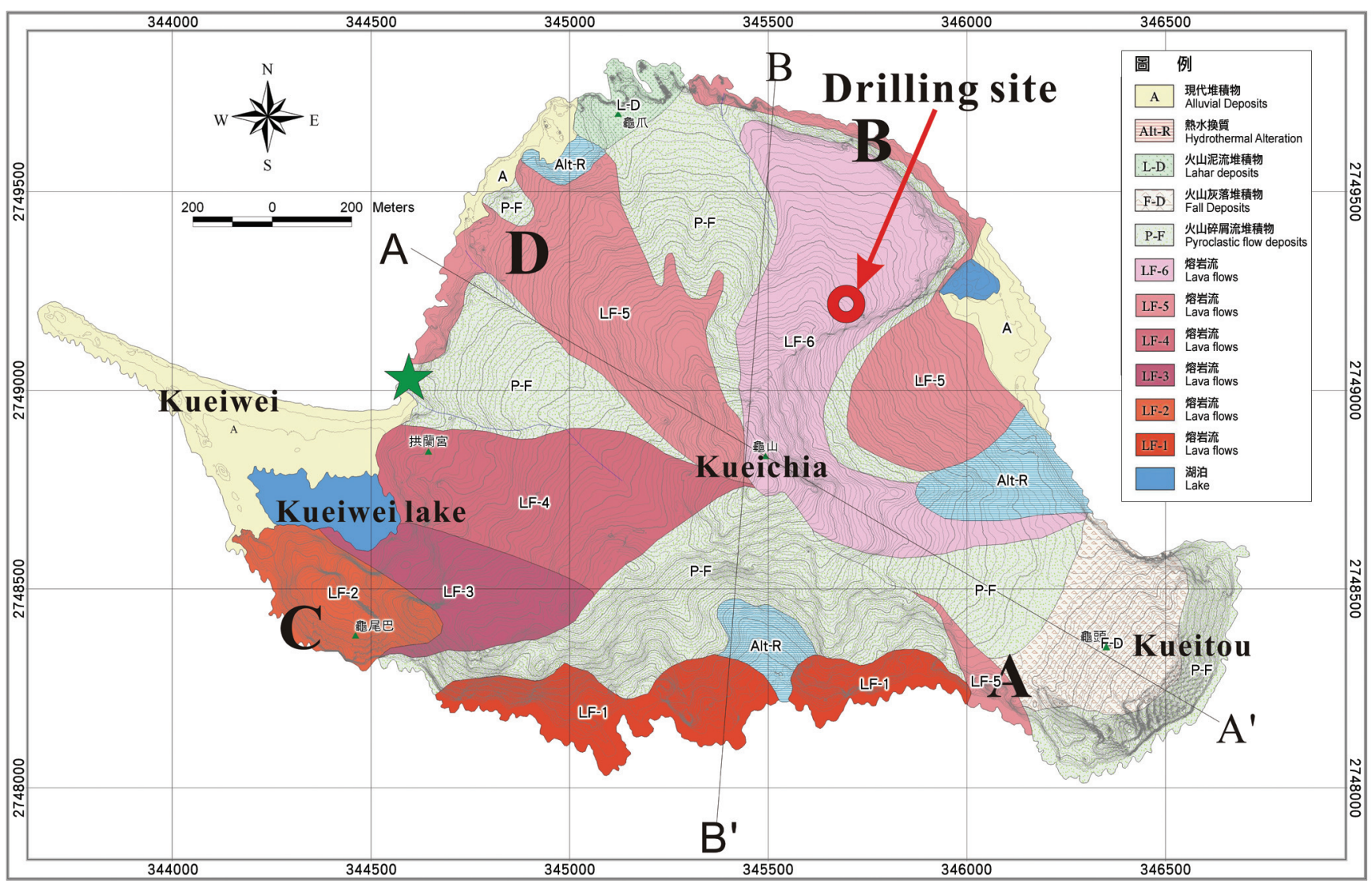

(b)

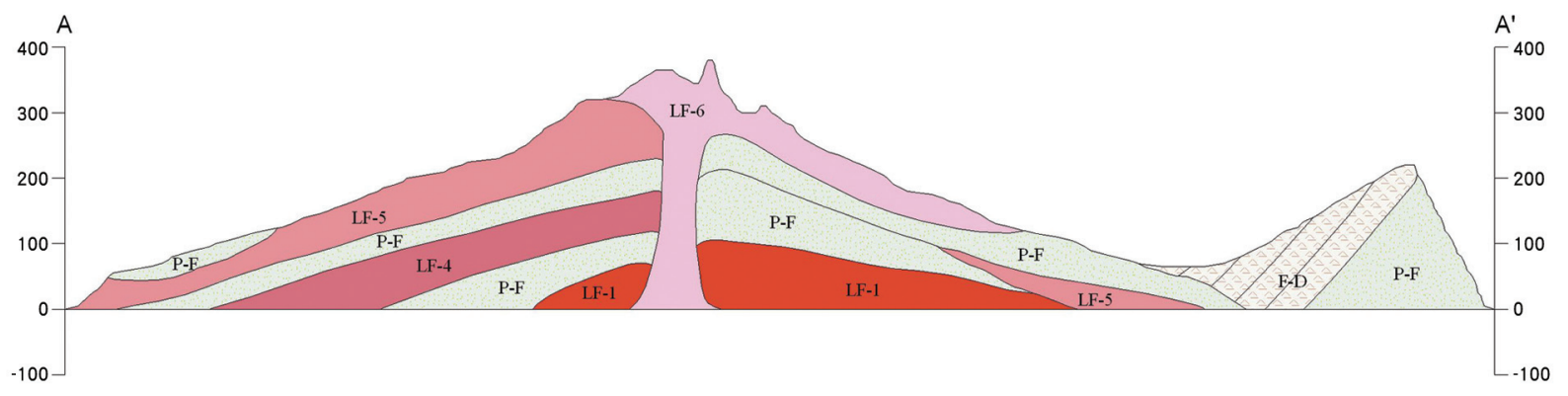

(c)

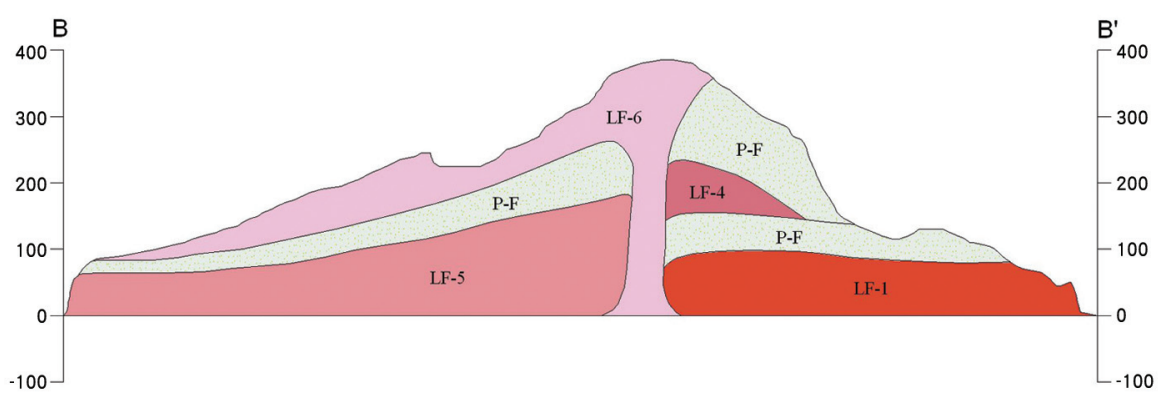

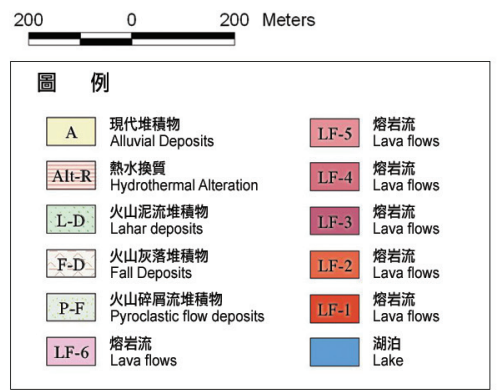

Fig. 4. Geological map and profiles. (a) Kueishantao is primarily composed of both lava flows and pyroclastic flow deposits, accompanied with minor lahar deposits, fall deposits, hydrothermal alteration and alluvial deposits. Topographically this island can be divided into three parts, i.e., Kueitou, Kueichia, and Kueiwei (Hsu 1963). Marks A to D represent the photographic locations of Fig. 3 and the star is the dating sample location of Chen et al. 2001. (b) Profile A - A' and (c) Profile B - B' showing the 401 highland is the potential eruptive center of the Kueichia volcano. 
is necessary and field investigation taking advantage of advances in volcanology is required.

In this study, the principles of geological mapping and determinations of the volcanic sequence are as follows. First, based on the characteristics of DTM and topography, they are caused by the occurrence of volcanic rocks. For instance, the margin of a lava flow generally forms a steep slope, and the top easily forms a plateau. Further, a lava flow also forms a ridge as a result of that it is much harder than a pyroclastic flow and can be preserved well. Second, based on the stratigraphic relations of volcanic rocks, the relationships of superposition and cross-cutting are determined. Finally, as for the Kueitou area, we only refer to the previous study (Hsu 1963) due to its inaccessibility.

Following the aforementioned principles, we proposed an updated geological map (Fig. 4). Our mapping shows that KST is probably composed of two volcanoes, i.e., Kueitou and Kueichia. The former was formed by pyroclastic flow deposits and ash fall deposits. The main part of this volcano has collapsed, including its vent. The latter was formed chiefly by interlayered lava flows and pyroclastic flow deposits. According to the fan-shaped distribution of lava flows, we can trace back to the potential eruptive center of the Kueichia volcano, which is at the 401 highland (401 $\mathrm{m}$ in altitude) of Kueichia. According to Hsu (1963), the eruptive center of the Kueichia volcano lies close to the south of Kueichia and has mostly collapsed into the sea. However, our observation suggests that the eruptive center of this volcano should be at the 401 highland and only part of the south volcanic edifice has collapsed.

In the geological map, we have identified six strata of lava flows, named as LF-1 to LF-6, from the bottom to the top respectively. The lava flow of LF-1 is mostly exposed at the lower part of southern cliff of Kueichia and is partially suffered from hydrothermal alteration as a result of volcanic activities in this area. The lava flow of LF- 2 forms the lava dome located at the southwestern part of Kueichia and topographically forms a hill. This lava flow appears to be very massive and fresh. Topographically, the lava flow which lies above LF-2 and near the Kueiwei Lake is identified as LF-3. The rest of the lava flows (LF-4, LF-5, and LF-6) are exposed at the west and the north, showing a fan-shaped distribution with clockwise spread. There are several layers of pyroclastic flow deposits interlayered among them. LF-5 is exposed at the outcrop of a landslide in the northeastern flank of Kueichia. In addition, because of the ash fall deposit layers on the top of the pyroclastic flows of Kueichia, we believe that the last eruption of the Kueitou volcano should be later than that of the Kueichia volcano. It is interesting to note that LF-5 and LF-6 both possess reddish surface exposed on the northern shore, shown in Fig. 3c. Additionally, xenoliths such as quartzite can be found in each lava flow and pyroclastic flow, particularly in LF-5, LF-6 and interlayered pyroclastic flows (Fig. 3d).

\section{CHARACTERISTICS OF THE CORES}

For the purpose of this study, two cores (core A and core B) at the northeastern flank of Kueichia have been drilled by the Central Geological Survey, MOEA. For core A, we retrieved the drill core sample from the surface to the depth of $140 \mathrm{~m}$, and then from the depth of 70 to $290 \mathrm{~m}$ for core B. The lithology of cores A and B, shown in Fig. 5, illustrates that there are at least twelve strata of lava flows interlayered with pyroclastic flow deposits and lahar deposits. Therefore, the KST is a typical stratovolcano and the eruptions might have occurred frequently in the past. For the upper $110 \mathrm{~m}$ of both core A and core B, the xenoliths of each flow can be easily identified while few of them or none can be found below this depth. In this study, we calculated the amount of xenoliths in the drill cores (Table 1). The top section of core A exhibits a reddish surface and can be correlated with LF-5 and LF-6 for similar color and elevation of exposed outcrops.

\section{DISCUSSION}

\subsection{Condition of the Eruptions}

In the past, KST was generally considered to be an underwater eruption because it is an island located offshore of northeast Taiwan. However, we did not find strong evidence of an underwater eruption, such as pillow lavas, pillow breccias or hyaloclastites which form by rapid cooling of magmas in the water and rims by chilled glass selvedges. Instead, many characteristics and occurrences of subaerial eruption like massive lava, blocky lava, Aa lava with redbrownish surface due to the thermal oxidation with the air. Moreover, several fan-shape lava plateaus radiated from the summit of volcano to the north and northwest indicate slow cooling of fluidized magma occurred in the eruptions. Those lines of evidence suggest that the KST volcano should be the product of subaerial activities. Compared with the sea level fluctuations now and in past, it can be inferred that KST may experience a significant eruption in the periods of low-stand sea level.

\subsection{Crustal Contamination}

Chen et al. (1995) reported that on the basis of very high $\mathrm{Sr}$ ratios $\left({ }^{87} \mathrm{Sr} /{ }^{86} \mathrm{Sr}>0.705\right)$, KST volcanic rocks were caused by about $30 \%$ crustal contamination when the magma passed through the thick continental crust and/or the overlying sediments during the onset of the "rifting" stage of the Okinawa Trough. Meanwhile, abundant crust xenoliths, such as quartzite, schist, hornfel and sandy pelite (Hsu 1963) have been observed in the field occurrences. Moreover, dispersed quartz xenocrysts and/or aggregates and cordierite (Chen 1990) also have been widely examined under the optical microscopy. All lines of evidence show 
(a)

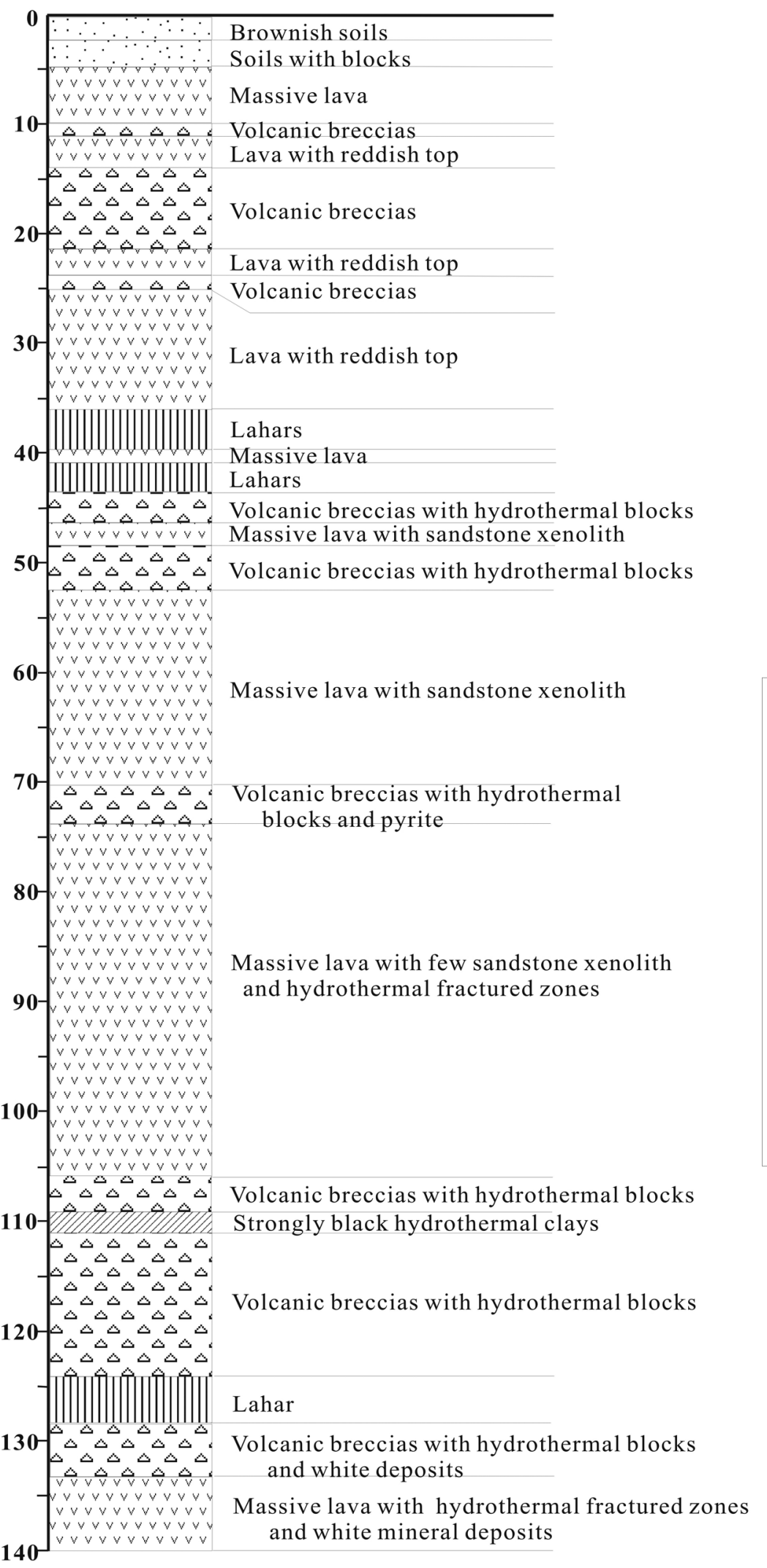

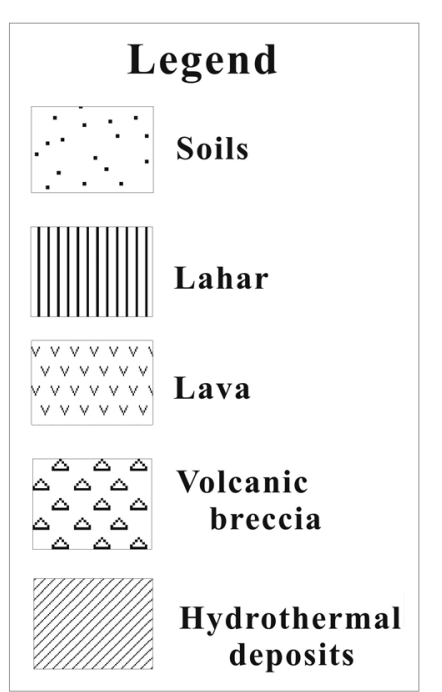

Fig. 5. Lithologic columns of cores A and B. (a) Core A. (b) Core B from 70 to $210 \mathrm{~m}$ in depth. (c) Core B from 210 to $290 \mathrm{~m}$ in depth. 
(b)

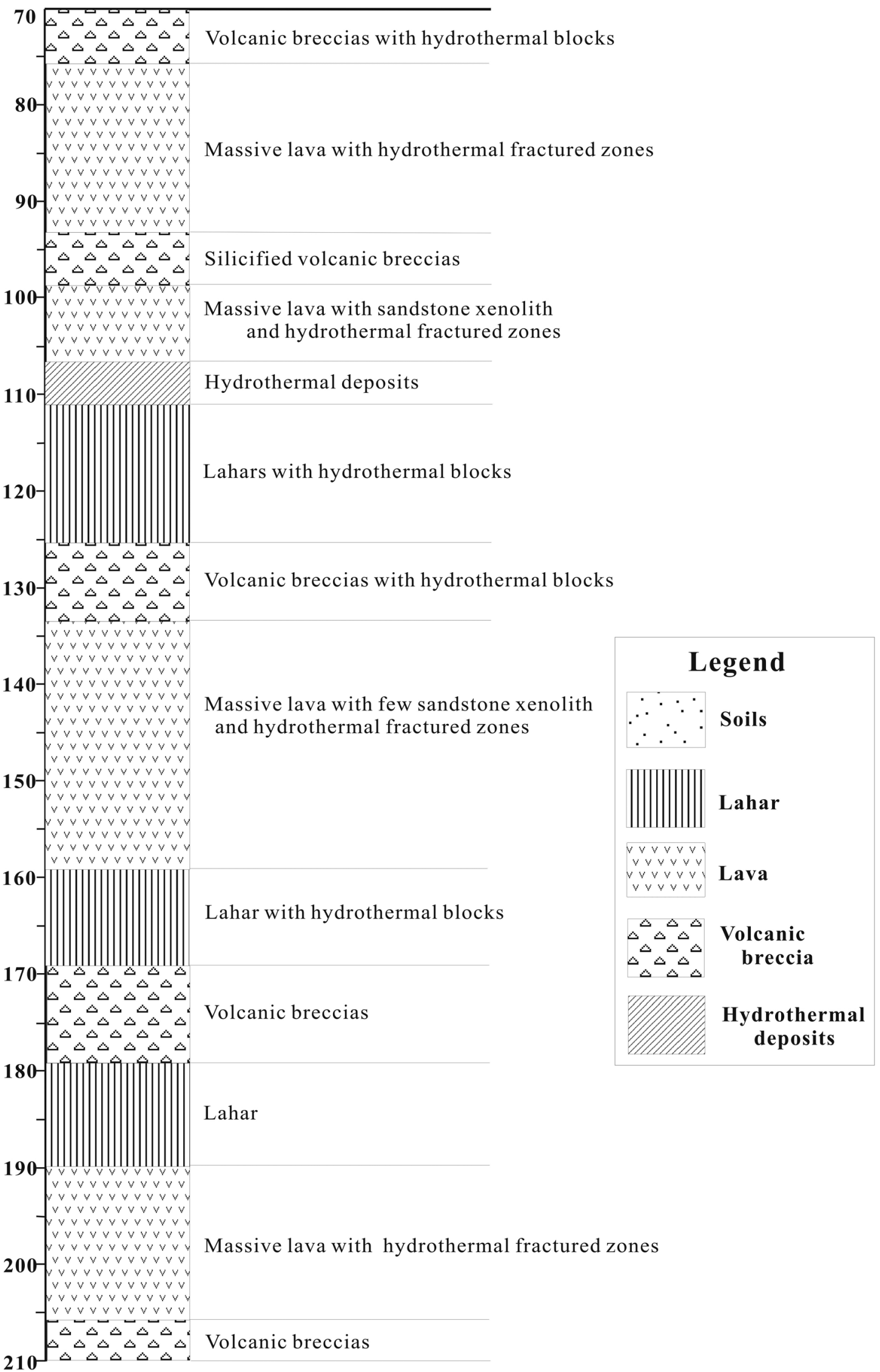

Fig. 5. (Continued) 
(c)

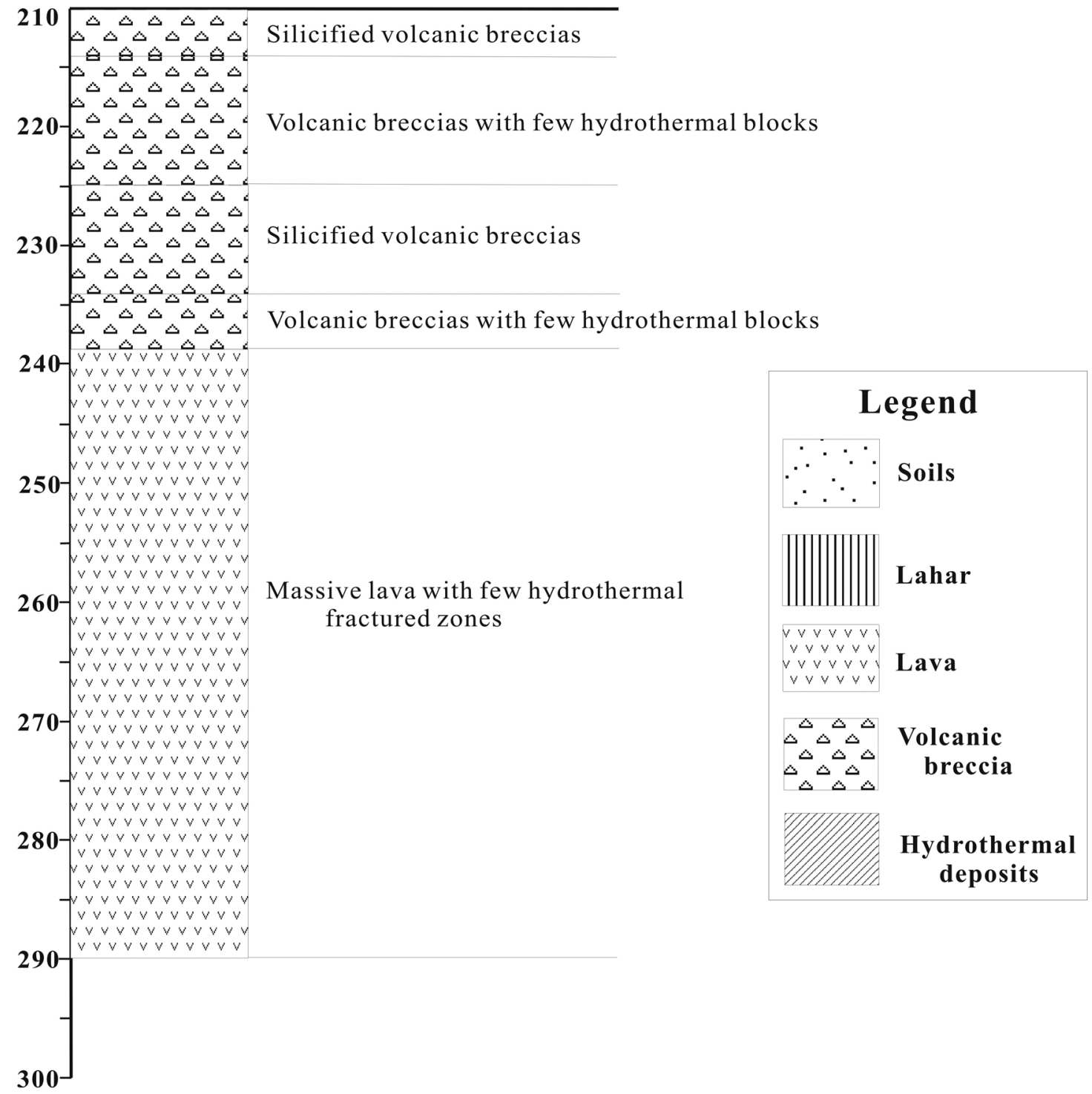

Fig. 5. (Continued)

Table 1. Statistics of the xenoliths in lavas of the cores.

\begin{tabular}{|c|c|c|c|c|}
\hline Core depth (m) & Lava thickness (m) & Amount & Total area $\left(\mathrm{cm}^{2}\right)$ & $\begin{array}{c}\text { Total area/ } \\
\text { Lava thickness }\left(\mathrm{cm}^{2} \mathbf{m}^{-1}\right)\end{array}$ \\
\hline $\begin{aligned} 4.8 & \sim 10.0 \\
11.0 & \sim 14.0\end{aligned}$ & 8.2 & 7 & 34.13 & 4.16 \\
\hline $\begin{array}{l}21.5 \sim 23.6 \\
25.0 \sim 36.0\end{array}$ & 13.1 & 23 & 78.21 & 5.97 \\
\hline $\begin{array}{l}46.5 \sim 48.5 \\
52.2 \sim 70.0\end{array}$ & 19.8 & 11 & 31.15 & 1.57 \\
\hline $73.7 \sim 106.3$ & 32.6 & 12 & 11.08 & 0.34 \\
\hline $133.0 \sim 159.0$ & 26.0 & 8 & 18.56 & 0.71 \\
\hline $190.0 \sim 204.7$ & 14.7 & 1 & 1.36 & 0.09 \\
\hline $240.0 \sim 290.0$ & 50.0 & 0 & 0.00 & 0.00 \\
\hline
\end{tabular}


that the magmas of KST have suffered from crust contamination before eruption. According to calculated contents of crust xenoliths enclaved in the lava (Table 1), the data show that the amount of xenoliths in the drill cores increases from the bottom to the top, inferring that the degree of crustal contamination increases progressively. Furthermore, Liu (1995) reported that the rifting of the Okinawa Trough has been extending through KST into the I-lan Plain. Thus, we suggest that the increasing degree of crustal contamination was probably caused by the opening of the Okinawa Trough. As a result of the opening of the Okinawa Trough, magma can more easily assimilate continental crust materials during it ascent through the upper continental crust.

\subsection{Formation of KST Volcano}

Two volcanoes have been recognized on KST in terms of topography and strata of volcanic deposits (Fig. 4). One is located in the Kueichia, while the other in the Kueitou. However, they have been partially destroyed by late weathering and erosion, especially for the relic halved Kueitou volcano. Most of the east part of the volcanic edifice has collapsed below sea level triggering abundant bubble upwelling from the submarine fumaroles.

At least six lava flows on the surface outcrops and twelve lava flows in the drilled cores interlayered with pyroclastic deposits, have been noted in the Kueichia volcano. Increasing crust xenoliths and xenocrysts from bottom to the top sequences in the lavas suggest that the degree of crustal contamination may be enhanced by the extensional stress region, which was correlated to the opening of the Okinawa Trough. Thus, a formation scenario of the KST volcanoes with present geomorphology can be proposed based on previous data and this study. Magma with arcaffinity (Chen et al. 1995) rose and erupted to the surface in northeast Taiwan to form a subaerial volcano, the Kueichia volcano during the period of low sea level. Following the opening of Okinawa Trough with propagation from the northeast to the southwest (Sibuet et al. 1998), volcanism may have intensified wherein abundant crust xenoliths were captured in the lava. After that, volcanism migrated a little to the east to build up the Kueitou volcano. Densely weathering and erosion worked on those two volcanoes during the rest of activity with the rising of sea level and increasing hydrothermal alteration to shape volcanoes as found in present morphology.

\subsection{The Potential Volcanic Hazards}

The possibility of a volcanic eruption can not be excluded in future based upon present data of those noting young eruption ages (Juang and Chen 1989; Chen et al. 2001), active fumaroles and a high magma-derived helium isotopic ratio (Yang et al. 2005). The general volcanic products of the KST include lava flows, ash fall, pyroclastic flows, and lahar. However, because KST is an offshore islet without inhabitants, only ash fall might affect the inland area to the west, if the eruption occurs in winter that the prevalent wind will blow from the northeast to the southwest. Ash Falll deposits were wide distributed in the west slope of Kueitao that could be happened in the future. Haeckel et al. (2001) have reported that in June of 1991, a series of the eruptions occurred at Mount Pinatubo, Philippines, and then the ash was transported in western and southwestern direction across the South China Sea (Wiesner et al. 1995). The total bulk volume of ash fallout was estimated to be around $5.5 \mathrm{~km}^{3}$, and covered area at least $3.7 \times 10^{5} \mathrm{~km}^{2}$. Although the eruption magnitude of the KST volcano may not be as huge as of the Pinatubo volcano, it still has great potential to induce the inpact of the ash fall.

In addition, a volcanic eruption could trigger a major landslide and lead to the generation of a tsunami. For examples, in 1792, a large earthquake followed the eruption of Unzen volcano and triggered a large-scale collapse of an old lava dome (Mt. Mayuyama) to cause the debris avalanche and resultant tsunami (Francis 1993). In KST, we have observed a relic landform of a landslide on the northeastern flank of the island (Fig. 2b) and of similar dimension to that of Mt. Mayuyama. This implies that the collapse of the KST volcano may have the potential to induce catastrophic tsunamis into the I-lan plain in the future. The layers of lava flows form dip slopes in the northern and northwestern flanks of the KST. The hydrothermal alterations are still active and weaken the volcanic rocks about the steep coastal cliff around the island that create landslide conditions triggered by an earthquake. We, therefore, propose that KST is capable of inducing volcanic hazards, especially for ash falls and tsunamis in the vicinity of northern Taiwan which requires further survey and long-term monitoring.

\section{CONCLUSION}

(1) In this study, we established a new 1/5000 geological map and divided the exposed volcanic rocks into six lava flows interlayered with pyroclastic flows. Therefore, the KST can be categorized as a typical stratovolcano which had gone through a long duration of explosive eruptions and has been modified by the syn- and post-volcanic processes, e.g., hydrothermal alteration, mass-wasting, and edifice collapse.

(2) Based on the occurrences of the volcanic rocks, including massive lava, blocky lava, Aa lava with red-brownish surface due to the oxidation with the air, we here suggest that the KST volcano should be the product of the subaerial eruption.

(3) The occurrence of xenoliths shows an increasing trend from the bottom of our drilling core to the top and in- 
fers an intensification of crustal contamination probably caused by the opening of the Okinawa Trough.

(4) We have observed a relic concave slope caused by an ancient landslide on the northeastern flank of the island, implying that the collapse of the KST volcano might have the potential to induce catastrophic tsunamis into inland area in the future.

(5) The possibility of volcanic eruption of KST in the future can not be excluded. Thus, long-term monitoring of volcanic activities around KST should be required for future hazard assessments.

Acknowledgements We thank C. W. Chen of the Central Geological Survey, Y. C. Lin and J. L. Jeng of the institute of Geosciences, National Taiwan University for their help in the field. We also thank S. Y. Huang (the institute of Geosciences, National Taiwan University) for her comments. The grants of this study were supported by the Central Geological Survey of Taiwan.

\section{REFERENCES}

Cas, R. A. F. and J. V. Wright, 1987: Volcanic Successions: Modern and Ancient: A Geological Approach to Processes, Products and Successions. Chapman \& Hall, $528 \mathrm{pp}$.

Chen, C. H., 1990: Igneous Rocks in Taiwan. Cent. Geol. Surv., MOEA, Taiwan, ROC, 137 pp. (in Chinese)

Chen, C. H., T. Lee, Y. N. Shieh, C. H. Chen, and W. Y. Hsu, 1995: Magmatism at the onset of back-arc basin spreading in the Okinawa Trough. J. Volcanol. Geotherm. Res., 69, 313-322, doi: 10.1016/0377-0273(95) 00028-3. [Link]

Chen, Y. G., W. S. Wu, C. H. Chen, and T. K. Liu, 2001: A date for volcanic eruption inferred from a siltstone xenolith. Quat. Sci. Rev., 20, 869-873, doi: 10.1016/ S0277-3791(00)00047-0. [Link]

Chung, S. L., S. L. Wang, R. Shinjo, C. S. Lee, and C. H. Chen, 2000: Initiation of arc magmatism in an embryonic continental rifting zone of the southernmost part of Okinawa Trough. Terr. Nova, 12, 225-230.

Francis, P., 1993: Volcanoes, A Planetary Perspective. Ox- ford University Press Inc., NY.

Haeckel, M., J. van Beusekom, M. G. Wiesner, and I. Konig, 2001: The impact of the 1991 Mount Pinatubo tephra fallout on the geochemical environment of the deepsea sediments in the South China Sea. Earth Planet. Sci. Lett., 193, 151-166.

Hsu, L. C., 1963: Petrology of the Pleistocene andesite from Kueishantao, Northern Taiwan. Acta Geol. Taiwan., 10, 29-40.

Juang, W. S. and J. C. Chen, 1989: Geochronology and geochemistry of volcanic rocks in northern Taiwan. Bull. Cent. Geol. Surv., 5, 31-66. (in Chinese)

Lee, C. S., G. G. Shor, Jr., L. D. Bibee, R. S. Lu, and T. W. C. Hilde, 1980: Okinawa Trough: Origin of a back-arc basin. Mar. Geol., 35, 219-241, doi: 10.1016/0025-32 27(80)90032-8. [Link]

Letouzey, J. and M. Kimura, 1986: The Okinawa Trough: Genesis of a back-arc basin developing along a continental margin. Tectonophysics, 125, 209-230, doi: 10. 1016/0040-1951(86)90015-6. [Link]

Liu, C. C., 1995: The Ilan plan and the southwestward extending Okinawa Trough. J. Geol. Soc. China, 38, 229242.

Sibuet, J.-C., B. Deffontaines, S. K. Hsu, N. Thareau, J.-P. Le Formal, C. S. Liu, and the ACT Party, 1998: Okinawa Trough backarc basin: early tectonic and magmatic evolution. J. Geophys. Res., 103, 30245-30267, doi: 10.1029/98JB01823. [Link]

Szakács, A., 1994: Redefining active volcanoes: A discussion. Bull. Volcanol., 56, 321-325, doi: 10.1007/BF00 326458. [Link]

Wiesner, M. G., Y. Wang, and L. Zheng, 1995: Fallout of volcanic ash to the deep South China Sea induced by the 1991 eruption of Mount Pinatubo (Philippines). Geology, 23, 885-888, doi: 10.1130/0091-7613(1995) 023<0885:FOVATT>2.3.CO;2. [Link]

Yang, T. F., T. F. Lan, H. F. Lee, C. C. Fu, P. C. Chuang, C. H. Lo, C. H. Chen, C. T. A. Chen, and C. S. Lee, 2005: Gas compositions and helium isotopic ratios of fluid samples around Kueishantao, NE offshore Taiwan and its tectonic implications. Geochem. J., 39, 469-480. 